NATURE | NEWS

\title{
How plants evolved into carnivores
}

Distantly related plants acquired their ability to eat meat through similar genetic changes.

\section{Ewen Callaway}

06 February 2017

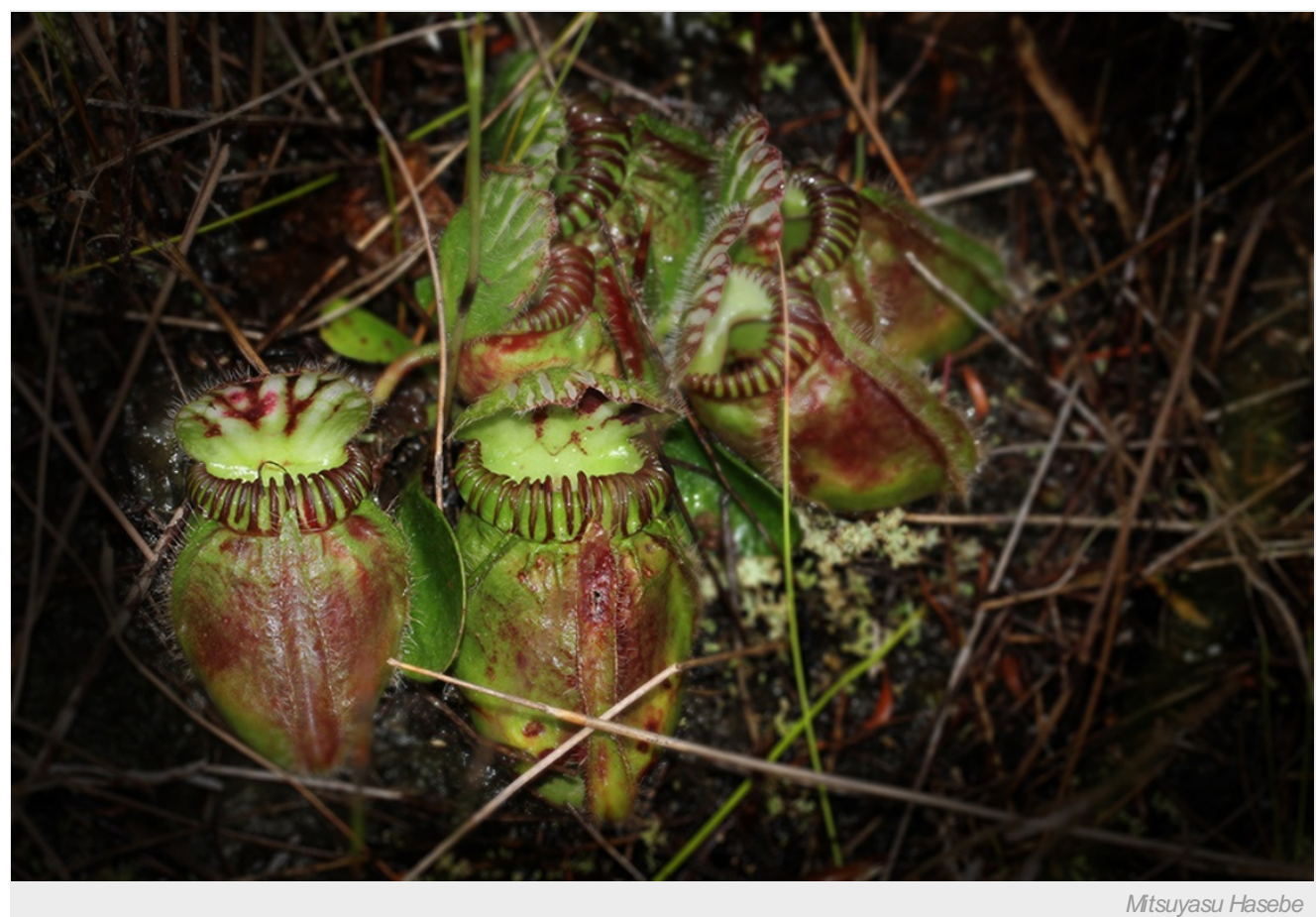

Carnivorous plants the world over, including the Australian pitcher plant (pictured), co-opted proteins used in defense to digest their prey.

Any insect unlucky enough to land on the mouth-like leaves of an Australian pitcher plant will meet a grisly end. The plant's prey is drawn into a vessel-like 'pitcher' organ where a specialized cocktail of enzymes digests the victim.

Now, by studying the pitcher plant's genome — and comparing its insect-eating fluids to those of other carnivorous plants researchers have found that meat-eating plants the world over have hit on the same deadly molecular recipe, even though they are separated by millions of years of evolution.

"We're really looking at a classic case of convergent evolution," says Victor Albert, a plant-genome scientist at the University of Buffalo, New York, who co-led the study ${ }^{1}$, published in Nature Ecology and Evolution on 6 February.

Carnivorous plants occur across the flowering-plant family tree. The Australian pitcher plant (Cephalotus follicularis) — native to a sliver of coastline in Southwest Australia - is closer kin to the starfruit (Averrhoa carambola) than to other species of pitcher plants found in the Americas and southeast Asia. This suggests that carnivory has evolved repeatedly in plants, probably to cope with the nutrient-scarce soils in which they grow, Albert says. "What they're trying to do is capture nitrogen and phosphorus from their prey."

\section{Deadly recipe}

Australian pitcher plants produce deadly 'pitcher' leaves — which resemble a toothy grin — as well as flat leaves. After sequencing the species' genome, Albert's team identified genes that are activated differently between the pitcher-like leaves and the plant's other, non-carnivorous, leaves. These included genes involved in making starches and sugars that may help to produce the nectar that lures insects to their deaths, as well as genes encoding waxy substances that may make it hard to escape from the pitcher.

To determine how pitchers eat their prey, the researchers sampled the digestive cocktail from Cephalotus and several other unrelated carnivorous plants and identified a total of 35 proteins, using mass spectrometry. Many of the proteins are related to those that other flowering plants use to fend off pathogens ${ }^{2-5}$. For instance, plants typically produce enzymes that break down a polymer called chitin 
as a defence against fungi, which make their cell walls out of the chemical. But Albert suspects that Australian pitchers and other carnivorous plants have repurposed the enzyme to digest insect exoskeletons, which are also made of chitin.

In the new analysis, Albert and his colleagues also found that in distantly related carnivorous plants, including species of pitcher plants, the genes deployed to make the digestive-fluid proteins have a common evolutionary origin. What's more, some of these genes have independently evolved to change the shape of the enzymes they encode in similar ways in the different species. The researchers don't have proof yet, but they think that the mutations might help to stabilize the enzymes when they are present together in digestive fluid.

While researchers already appreciated the importance of convergent evolution for carnivorous plants, says Aaron Ellison, an ecologist at Harvard Forest in Petersham, Massachusetts, the new study is important because it demonstrates how this convergence can occur down to the molecular level, he says.

Gaining the ability to eat an insect is of little use if a plant cannot first entrap one, and here evolution has come up with more diverse solutions, Albert notes. Venus fly-traps ensnare their prey, whereas bladderworts immobilize their victims using tiny suction cups. In his 1875 book Insectivorous Plants, Charles Darwin included detailed drawings of the tentacles that sundews use to pin insects to their leaves. "It's no wonder Darwin wrote an entire book on carnivorous plants," Albert says.

Nature | doi:10.1038/nature.2017.21425

\section{References}

1. Fukushima, K. et al. Nature Ecol. Evol. 1, 0059 (2017).

2. Buch, F. et al. Ann. Bot. 111, 375-383 (2013).

3. Schulze, W. X. et al. Mol. Cell. Proteomics 11, 1306-1319 (2012).

4. Michalko, J. et al. Planta 238, 715-725 (2013).

5. Bemm, F. et al. Genome Res. 26, 1-14 (2016). 